\title{
Marx As Journalist: Revisiting The Free Speech Debate
}

\author{
Padmaja Shaw \\ Professor, Department of Communication and Journalism, Osmania University, Hyderabad \\ 500044, India. padmajashaw@gmail.com
}

\begin{abstract}
Marx was a practicing journalist for most of his adult life. He was editor, columnist and special correspondent at different times and his journalistic work provided significant inputs for his later theoretical work. Marx, through his engagement with the political revolutions of $19^{\text {th }}$ century Europe, developed one of the finest arguments in defence of free speech and the need for expanding bourgeois democratic freedoms in the process of transition to socialism. This paper describes the role of the Marxist parties and intellectuals in India in using and expanding the democratic freedoms available in India. The paper concludes that there is a gap between Marx's ideological position on free speech and the praxis of Marxist parties. In contemporary India, there is urgent need to protect free speech, fight censorship and strengthen independent constitutional authorities that are governed by democratic principles.
\end{abstract}

Keywords: Bourgeois democracy, Free speech, Indian left politics, Indian press, Marxism, Socialism

Acknowledgement: I would like to express my gratitude to Prof. G. Haragopal, eminent human rights activist and retired professor of Political Science, University of Hyderabad, for his comments on this paper.

\section{Introduction}

All of 169 years after Karl Marx began his career as a journalist in Europe with a brilliant defence of free speech in 1842, in 2011 a fresh debate has arisen on free speech as it is understood and practiced all over the world. While the people fighting repressive regimes are struggling to win basic freedoms of life, liberty, association and speech, the people in liberal democracies are demonstrating on the streets their sense of outrage at the loss of those very freedoms of life, liberty, association and speech that globalised capitalism has taken away.

Analysts have likened the current global crisis of capitalism to the conditions prevailing across Europe at the time of the revolutions of 1848 . The $20^{\text {th }}$ century consensus about bourgeoisdemocracy being the most stable formation is being challenged.

Throughout history, the relationship between democratic struggles and the goals of establishing working class control over production have remained problematic and sometimes have been lost sight of. While it is the thesis of Marxian analysis that the problem lies in the capitalist mode of production and its unbridled quest for profits, which tries to prevent the inevitable emergence of working class as a dominant force, twentieth century saw the unprecedented use of media as instruments for promoting the interests of global capital.

Media industries have played a major role in building and sustaining the prevailing social consensus around the notion of bourgeois-democratic stability. The gradual corporatisation of media has made them an integral part of the circuit of capitalist production, and major players in creating and sustaining capitalist societies. Given this, can we expect the corporate media industry to protect the rights of the people? Are the 'free' media institutions in democratic societies providing space for working class struggles? Is it possible for the journalist working for a media corporation to question the basic premises of bourgeois democracy?

It is necessary to revisit Karl Marx's works to understand his conception of free speech, both for the ideological framework he has developed as well as for the remarkable and radical role he played as a journalist all his adult life. Marx has written extensively as a journalist on every important issue for a good part of the 19th century (1842 to 1865) covering the revolutionary awakening that gripped much of Europe and elsewhere. During these years he edited Rheinische Zeitung, Neue Rheinische Zeitung, contributed to a variety of papers both in German and in English, which included The People's Press, Die Presse, Neue Oder Zeitung, and several other papers including around 487 (125 by Engels, jointly with Engels 12, singly 350) articles for The New York Tribune as 
its Europe correspondent. Though while he was writing for The New York Tribune, since the English language translation of the Communist Manifesto was still not available, Marx was not known widely as the author of the revolutionary document in the English speaking world (Ledbetter 2007). Marx's column in The New York Tribune was welcomed because of its concern with people's issues, that matched founder Horace Greeley's stated objective for starting the Tribune as a sensible counter to the frivolous penny press of his time (Emery and Emery 1954, 124).

Three major aspects that Karl Marx deals with in his journalistic writings have a deeply contemporary resonance in countries like India: freedom of speech and censorship, the press as a part of free trade, and the role of media in bourgeois democracies. This paper will present Marx's major arguments on all the three issues and will then examine the role of left parties and intellectuals in India, a bourgeois democracy that constitutionally guarantees free speech.

\section{Free Speech And Censorship}

In the 1840s, much of Europe was ruled by despotic monarchs. Journalists and writers were constantly subjected to stringent censorship, as most of the countries had no traditions of free speech or a Bill of Rights that guaranteed any rights. (Padover 1974, xi). In 1841, the Prussian cabinet issued a censorship decree that expanded the scope of the existing censorship edict, to suppress anything that was critical of the "fundamental principles of religion and offensive to morality and good will".

Karl Marx, a young Hegelian at 24, burst on to the political scene of Germany with his incisive analysis of freedom of speech and censorship. In a series of articles published in Rheinische Zeitung between May 5 and 19, Marx posed an impassioned challenge to the pronouncements of the elected representatives of the Sixth Rhineland Landtag on censorship:

"The censorship law ... is not a law, it is a police measure; but it is a bad police measure, for it does not achieve what it intends, and it does not intend what it achieves. ... The censorship makes every forbidden work, whether good or bad, into an extraordinary document, whereas freedom of the press deprives every written work of an externally imposing effect". (Padover 1974, xiii)

Marx's opposition to censorship was not driven by any desire for an unregulated press. He argued for press laws that would be administered by independent judiciary:

“... censorship ... makes arbitrariness into a law. ... Just as a press law is different from a censorship law, so the judge's attitude to the press differs from the attitude of the censor.

... The independent judge belongs neither to me nor to the government. The dependent censor is himself a government organ ... The judge has a definite press offence put before him; confronting the censor is the spirit of the press. The judge judges my act according to a definite law; the censor not only punishes the crime, he makes it ... The censorship does not accuse me of violating an existing law. It condemns my opinion because it is not the opinion of the censor and his superiors. My openly performed act, which is willing to submit itself to the world and its judgment, to the state and its law, has sentence passed on it by a hidden, purely negative power, which cannot give itself the form of law, which shuns the light of day, and which is not bound by any general principles".

"A censorship law is an impossibility because it seeks to punish not offences but opinions, because it cannot be anything but a formula for the censor, because no state has the courage to put in general legal terms what it can carry out in practice through the agency of the censor. For that reason, too, the operation of the censorship is entrusted not to the courts but to the police." (Italics in original) (Marx 1842a) 
Describing true censorship as criticism that is the very essence of freedom of the press, Marx argued that censorship is criticism as government monopoly, but that the government wants to apply it in secrecy and does not itself want to suffer any criticism (Marx 1842b). Drawing a further distinction between press law and censorship he wrote:

"In a press law, freedom punishes. In a censorship law, freedom is punished. The censorship law is a law of suspicion against freedom. The press law is a vote of confidence which the press gives itself. The press law punishes the misuse of freedom. The censorship law punishes freedom as misuse. ... Thus press law, far from being a repressive measure against freedom of the press, is merely a means to discourage repetition of violation through a penalty. ... Laws are not repressive measures against freedom, any more than the law of gravity is a repressive measure against movement. ... Rather, laws are positive, clear, universal norms, in which freedom has won an impersonal, theoretical existence independent of the caprice of any individual. ... Press law is the legal recognition of freedom". (Marx 1842c)

About freedom of the press, he wrote:

"The free press is the ubiquitous vigilant eye of a people's soul, the embodiment of a people's faith in itself, the eloquent link that connects the individual with the state and the world, the embodied culture that transforms material struggles into intellectual struggles and idealises their crude material form. It is a people's frank confession to itself... It is the spiritual mirror in which a people can see itself, and self-examination is the first condition of wisdom". (Marx 1842d).

For Marx, the press is the "most general way for individuals to communicate their intellectual being. It knows no reputation of a person, but only the reputation of intelligence" (Marx, 1842e). Marx believed that a revolutionary movement must participate in public life and educate the proletariat and that it is necessary to protect free speech, as newspapers are the primary instruments of public communication (Hardt 2000).

Writing on widespread distress in Mosel province, Marx explained the need for a free press:

"To solve difficulties, the administration and the administered need a third element, which is political without being bureaucratic, an element that does not derive from bureaucratic presuppositions, that is, civic without being directly entangled in private interests and their needs. This complementary element, composed of a political head and a civic heart, is a free press (italics in original). ... The "free press," as it is the product of public opinion, also produces public opinion, and it alone has the power to make a special interest into a general interest. .. It alone has the power to alleviate the misery, if for no other reason than that it distributes the feeling of misery among all" (Marx 1843).

By October of 1842, Marx became the editor of Rheinische Zeitung, his genius widely recognized. As editor of the paper, with regular contributions from Engels and other young Hegelians, Marx led a crusade for a unified Germany and championed working class issues. A significant aspect of Marx's early practice of journalism was his relentless effort to fight back all attacks on free speech, whether from state decrees or from lead articles in rival papers of the time like Kölnische Zeitung, which wielded significant influence among the conservative Christian readership of the province. Marx would use his incisive logic and biting wit to expose the hypocrisy of the rival newspapers, which supported various forms of repression of the Prussian state.

However, the two papers Marx edited between 1842 and 1849, Rheinische Zeitung and Neue Rheinische Zeitung, were hounded by the governments of the time and finally shut down. After the closure of Rheinische Zeitung, Marx left Germany, but returned in 1848 after the revolutionary changes to start Neue Rheinische Zeitung. In a point-by-point refutation of the Prussian Press Bill 
introduced by post-revolutionary Prussia, Marx exposed how the new bill was in glaring contradiction to press freedom:

"From the day this law goes into effect, the officials can commit any despotism, any tyranny, any illegality, with impunity; they can coolly flog or order to be flogged, arrest and hold without a hearing; the only control, the press, has been made ineffective... Indeed, what remains of freedom of the press if that which deserves public contempt can no longer be held up to public contempt?" (Marx 1848)

In a typical example of his sharp wit, he adds: "He (Herr Hansemann) should also declare it punishable to expose the officials to public ridicule besides penalising their exposure to public contempt. This omission might otherwise be painfully regretted".

Well before moving to Britain, Marx would mercilessly expose the deliberate attempts at antiworking class propaganda by some of the German newspapers. Marx demolished the 'curious things' Neue Berliner Zeitung reported on the leaders of the Chartist movement in England, (Marx 1848). In the prevailing context of authoritarianism and censorship, Marx also exposed the rights violations perpetrated by officials.

In 1849, Marx was compelled to leave Germany. He lived the rest of his life in London. He reported for The New York Tribune as Europe correspondent from August 1851 to February 1862. The New York Tribune grew rapidly and became the largest circulated English daily selling 300,000 copies. Marx was a leading and widely read economic journalist of his time. (Musto 2008, 163).

\section{On Free Trade And Free Press}

Individuals and investors espousing various ideological streams of the time owned the 19th century press in Europe and elsewhere. The issue of the status of free press and whether it can be subsumed under the general notion of "freedom of the trades" was debated in the legislatures of the time. Marx subjected the idea to detailed analysis. He argued: "freedom of the trades is only freedom of the trades and no other freedom, for in it the nature of the trade forms itself unhindered according to its own inherent rules; freedom of the courts is freedom of the courts, if the courts promote the inherent rules of the law, and not those of another sphere, such as religion. Every definite sphere of freedom is the freedom of a definite sphere..." (Marx 1842f). He said, to defend the freedom of a sphere, it has to be conceived in its essential character, not in its external relationships. " $\ldots$ is the press free which degrades itself to the level of a trade? The writer, of course, must earn in order to be able to live and write, but he must by no means live and write to earn. ... The primary freedom of the press lies in not being a trade. The writer who degrades the press into being a material means deserves as punishment for this internal unfreedom the external unfreedom of censorship, or rather his very existence is his punishment." (Marx 1842g; italics in original).

Marx, however, acknowledged that the press is also a trade, but it is not the business of the writer, but those of the printers and book dealers. Through a clear definition of the freedom of the press, Marx has charted a road map for using the spaces provided by liberal democracy for expanding the freedoms of the individual. Prof Haragopal ${ }^{1}$ (2012) says that rights define limits of freedom. In the bourgeois conception, the individual is seen as egoistic and confrontational and therefore there is a need to define the limits of freedom. When society is seen as a collective, such a limiting definition is not required. Human rights activists believe that individual freedom has to be reconciled with the collective freedoms and the two are not necessarily antagonistic.

Marx's analysis of press freedom and the status of the press as a trade have special significance to the politics of the left in bourgeois democratic countries like India, where the left has continued to play a constant if not significant role in the polity. Before discussing the left's role in expanding democratic freedoms through the press, a brief overview of the status of left politics in India is necessary.

\footnotetext{
${ }^{1}$ Personal interview, 16 March, 2012. Prof G. Haragopal, a political philosopher, eminent human rights activist, has retired as professor of Political Science from the University of Hyderabad.
} 


\section{The Left In India}

By the time India attained independence from British rule in 1947, there was a prominent left of centre political strand in the anti-colonial struggle. The 1917 Russian revolution influenced and inspired sections of the anti-colonial struggle (Nair 2009) in addition to the movement that was beginning to take shape by 1920 s under Mahatma Gandhi. Within the Indian National Congress itself, there were power centres of various ideological hues: bourgeois democratic thinking represented by Gandhi himself and Fabian socialism, represented by Jawaharlal Nehru, the first Prime Minister of independent India. Outside this circle, there were radical and revolutionary groups all over the country that were challenging the British rule with armed insurgencies of various intensities.

As elsewhere in the world with the left, the need to work with bourgeois-democratic form as the basis and from this to achieve socialist goals was the challenge in India too (Nair 2009). In the anticolonial struggle in India, some of the Marxist groups provided the intellectual and ideological basis and worked with the Gandhian/mainstream bourgeois mobilization, but radical revolutionary groups operating outside this sphere of influence carried out armed insurgencies in various parts of the country (Rajimwale 2009a).

India had 565 princely states before Independence. An autocratic Nizam ruled the Hyderabad state, considered the world's richest kingdom at that time. The repressive feudal regime gave rise to radical left-wing politics. At the cusp of national independence in 1947-48, an uprising, called the Telangana armed peasant struggle ${ }^{2}$, under the leadership of the left took control of over 3000 villages and began to implement radical reforms, the first of which being redistribution of land to the poor, then providing for schools and healthcare. (Pucchalapally 1971a).

However, the armed struggle was brutally suppressed by the newly independent Indian state using the Indian army, calling it "police action" (Pucchalapally 1971b). The police action was used to restore the redistributed land to the feudal lords, while promising land reforms to appease the people (Pucchalapally 1971c). The Communist parties were banned in 1948 and several of the leaders went under-ground. The armed struggles in Telangana, in Kerala and in Tripura, have been inspiring episodes in the history of the Indian communist movement but the following phase gave rise to several debates.

Firstly, when democratic elections were held in Andhra Pradesh, many of the communist leaders of the peasant movement got elected to the legislature with large majorities. In one of the southern states, Kerala, the first Marxist government in India came to power in 1957 through the electoral process (Rajimwale 2009b). Two decades later in eastern India, the Communist Party of India (Marxist) was elected to power in West Bengal in 1977 and was re-elected to power thereafter for 34 years in succession till 2011. The argument, therefore, of the possibility of the left attaining political power through democratic elections has remained significant, at least in some parts of India, while the constraints of the bourgeois democratic framework on elected left governments is still a matter of debate.

Secondly, strengthened by the electoral experience, Marxist groups that believed in using the bourgeois democratic base to achieve socialist objectives questioned the feasibility of taking on the might of a well-armed state through an armed struggle. The mainstream Marxist parties that have joined electoral politics consider the armed struggle adventurism. Earlier in 1964, this led to a formal split between the communist parties that espoused the revolutionary path and those that preferred democratic methods of achieving socialist goals. The revolutionary armed groups have splintered into several smaller groups since but have expanded their reach and presence significantly.

In 1967, another armed peasant insurgency from the Naxalbari area of West Bengal brought back radical left politics into the political discourse in India. This continues in various forms and levels of intensity in large parts of central India called the "red corridor", where some of the groups control the political and economic life in these areas. Some reports estimate that the Maoist influence has spread from an estimated 56 of India's 626 districts in 2001 to more than 200 districts by

\footnotetext{
*A detailed analysis of the armed struggle is available at: http://www.scribd.com/doc/15379761/Telangana-PeoplesArmed-Struggle-19461951-Part-One-Historical-Setting. P Sundarayya, an active participant/ideologue of the armed struggle, was General Secretary of CPIM
} 
2010 (The Economist ${ }^{3}$ 2010). They are also implementing radical left reforms such as redistribution of land, collectivization, literacy and health care for the people, in order to establish prototype communities. However, the state has been using special armed forces and special Acts to contain and repress these groups over the last 60 years with steady loss of life on both sides.

In contrast, the Communist parties that participate in the electoral politics have found that there has been a steady erosion of their political base among the proletariat as all the other political parties also have their own trade unions and student wings. The process of the "jobless economic growth" of the Indian economy since Independence, the breaking up of the industrial enclaves of textile, jute and other manufacturing activities that provided ideological coherence to trade unionism, the neo-liberal economic policies implemented since 1991, further contributed to the erosion of the proletarian base. The more insidious process of co-opting the vocabulary and mobilization techniques of the communist parties by the centrist and even the radical right groups has added to confusion about left identity in popular perception.

Other than the formally identifiable groups of the left, there are a large number of Marxist intellectuals, journalists, academicians, lawyers, judges, civil liberties activists and even bureaucrats, who like to characterize themselves as the "independent left". This is necessitated because in the left movement in India, groups have identified themselves with the Russian communists, with Maoism, Leninism, Trotskyism, Stalinism and so on. The independent left provides a vibrant ongoing critique and direction to the left movement in general, without espousing any later interpretations of Marxism.

The "parliamentary left" that comprises a set of left parties, which run left coalitions in some states and work together in parliament, face criticism from the "independent left". The "independent left" groups say that these parties lack internal democracy and are moulded on the discredited legacies of Stalinism. The "independent left" groups feel that the electoral loss and decline of left parties need not necessarily mean the decline of the Left in India. They feel that "the Left outside the parliament, the left as a culture of democracy and resistance, a network of movements and organisations, and a new more vigorous set of campaigns will continue to flourish" (Menon 2011).

The left groups that are engaged in the armed insurgencies have despised mainstream democratic struggles as irrelevant to the achievement of socialist goals. They question how an elected government can bring about radical transformation when it is compelled to work within the rigid framework of bourgeois democracy - with bureaucracy, judiciary and legislative processes that are designed to deny the rights of the working class.

\section{Journalism And The Left}

The presence of the left in journalism in India is as complex a tapestry as the larger canvas of the left political sphere. Its presence can be understood as the project of keeping the working class struggles in public discourse as a counter to the manufactured consensus around bourgeois democratic stability. The nature of left interventions in the media and understanding which kind of intervention helps in expanding the democratic values inherent in the Marxist praxis will provide lessons for the future.

There are three sources for the left of centre input in journalism in India: 1. The periodical publications by Marxist parties; independent left-of-centre entities; recently, web sites and party-run TV news channels, 2. "Left-leaning" intellectuals writing in mainstream newspapers and magazines, 3. Journalists working for national and regional media organizations.

"Left-leaning" is used here to broadly signify those who research and write about agrarian and industrial class struggles, political economy critique of state policy, the capitalist development paradigm and large-scale displacement of communities, the critique of caste and religious identity politics, human and civil rights issues, globalization and its consequences, the critique of capitalism and its impact on lives of the common people, etc. However, the writers identified below may not define themselves as "left leaning" or Marxist.

The journalists certainly would not like to be labeled as left or Marxist, as social concern without an ideological tag is their primary source of credibility. But there are several journalists who have

\footnotetext{
${ }^{3}$ The news item describes the nature of conflict accompanied by a detailed map of areas under Maoist influence.
} 
distinguished themselves by reporting on important political and economic developments from a left perspective.

\subsection{Publications By Marxist Parties, Independent Left-Of-Centre Entities}

\subsubsection{Marxist Party Periodicals}

The Marxist parties bring out printed publications - newspapers, magazines, and journals - as an integral part of their activities. Both the mainstream communist parties (Communist Party of India [CPI] and Communist Party of India Marxist [CPIM]) publish daily newspapers in English and in Indian languages in addition to periodicals meant for women's groups, students, industrial and agricultural workers.

The orientation of the publications is primarily to explain the "party line" and to spread information on mobilisation programmes. The parties are rigidly structured and hierarchy-bound, without much possibility of open debate on ideological issues. Therefore, it is rare to see party-run newspapers rigorously debating ideological issues. They concentrate on strategic positions the party will take in response to specific issues of the day. Because they are seen as tools for propaganda, none of them are widely circulated though they are quoted from when the party line is in debate in mainstream media. Both the mainstream media and the state agencies monitor these publications. The Marxist parties also maintain websites with historical and contemporary information. In 2011, the CPIM launched a TV news channel in Kerala.

Most of the splinter groups of the radical left maintain an active publications programme of booklets and pamphlets. The publications are intended primarily to inform the cadre but also to send a message to the outside world about their ideological position.

\subsubsection{Independent Left Publications}

Weekly publications like Mainstream, started in 1962 by the veteran Marxist and journalist Mr Nikhil Chakravartty, represent the independent left publications that are open to shades of left-of-centre opinion (Goyal 1998).

Economic and Political Weekly (Economic and Political Weekly website 2012) that has been published since 1949 (earlier known as Economic Weekly), is a unique publication that has been a platform for consistent and vibrant independent left scholarship. Academicians, journalists, human rights activists and others write both analytical commentaries on contemporary issues and wellresearched academic articles on social, cultural, political and economic matters that affect working class.

Mainstream and Economic and Political Weekly, both are published in English and have circulation among intellectuals and academicians. Neither of the publications has a popular base, but both have been economically viable mainly supported by subscription revenues and some noncommercial advertising. The founders of both the magazines have passed away but the new editors are carrying forward the traditions and the spirit of the publications.

In the new media era, Kafila (Kafila website 2012) is a collective blog by "independent left" intellectuals that began in October 2006. It has provided an independent platform for debate on contemporary issues. There are several other such publications/websites with similar spheres of circulation such as Frontier (Frontier website 2012) published from Kolkata and Counter Currents (Counter Currents website 2012) that have been sites for voicing dissent against the mainstream.

\subsection{Left-Leaning Intellectuals Writing For Mainstream Newspapers And Magazines}

There are a number of scholars and academicians who have been writing from a left perspective on politics and economics in India, sometimes through regular columns for newspapers and magazines. The Hindu and Frontline, both from a major publishing house from Southern India, Kasturi and Sons, has provided a platform over the years for left-leaning academicians and journalists. The Hindu is a 134-year-old newspaper based in the south Indian state of Tamil Nadu. It publishes out of 13 cities and has a circulation of 4.06 million (The Hindu Website 2012). It has a formidable reputation for integrity and professionalism. 
Frontline is a news magazine from the same publishing house and carries substantial number of in-depth analytical articles on a wide variety of topics. N Ram, who was the editor-in-chief of the group and edited both The Hindu and Frontline for several years, who had made no secret of his allegiance to the Communist Party of India (Marxist), has provided space for left-leaning writers like Praful Bidwai, CP Chandrashekhar, Jayati Ghosh, Aijaz Ahmed, a Marxist literary critic and Vijay Pershad, a Marxist historian. The magazine gives regular space to issues related to the working class, workers in unorganized sector, and issues of the tribal people (Frontline magazine 2012).

Others like Ashok Mitra, academicians like Utsa Patnaik and Prabhat Patnaik also have a significant presence in mainstream media. The columns written by some of the scholars are syndicated and publish in several newspapers and magazines. The widely circulated national newspapers and magazines have been providing spaces occasionally for multi-perspective debate, left of centre views being an important part of it.

\subsection{Journalists Working For National And Regional Media Organizations}

There are two categories of journalists, who have been active in the media: 1. Journalists working for the mainstream English media that occupy a large mind-space among the urban elite; 2 . Journalists who work for the language press with very large circulations among a particular language group.

\subsubsection{Mainstream English Language Media}

The total circulation of newspapers in India is 329 million copies. There are 82,222 registered newspapers in India (RNI website 2012). In both magazine and newspaper journalism, there have been several journalists in India, who have consistently addressed people's issues and used the news columns for building critical awareness about important issues in politics and economy of the nation.

Prominent among them is Vinod Mehta, till recently the editor-in-chief of the Outlook group, who describes himself as "left-liberal" (Mehta 2012a). During his distinguished career as a journalist, Mehta has broken major stories on anti-people policies of the state and cases of corruption, abuse of power and mis-governance. The stories have had national impact. The stories on industrial action by unions and special economic zones that were carried by Outlook also give a more rounded perspective, giving adequate space for the workers' point of view. The magazine Outlook also gave extensive space to the radical left opinion of Arundhati Roy, the Booker prize-winning author and activist. In an interview with Bhatt, Mehta said: "I am a Left Liberal, so Outlook is a Left Liberal magazine... I make sure ... the inequality of our people is reported. The government cannot say that market forces are going to determine anything and everything. We have a broad vision of what India should be like and we try, and I emphasise this word, we try in our publication to promote that idea" (Mehta 2012b).

Palagummi Sainath has been reporting on the agrarian crisis, the impact of globalization on the agrarian sector, the widespread rural distress leading to the suicides of thousands of farmers and handloom weavers. P Sainath is the Rural Affairs Editor of The Hindu. He has published a bestselling book, Everyone Loves a Good Draught, a compilation of a series of his reports on rural distress from various parts of rural India. Sainath was working with the largest circulated multi-edition newspaper, The Times of India, when he toured the rural areas in the country on a Times fellowship and published 84 op-ed reports (Thakurta 2012, 504).

Sainath says that the media in India are politically free, but are imprisoned by the profit motive of their proprietors. He says that in the worst of newspapers one might still find spaces where they talk of poverty and agrarian distress, but for that people have to die in sufficiently large number to merit the news space (Palagummi 2011). He says that almost anything that is worthwhile in journalism is born out of dissent. No establishment journalist has ever been considered great (Palagummi 2008).

Paranjoy Guha Thakurta, who has worked with newspapers such as the The Telegraph and news magazines like India Today, is also a television commentator. Thakurta published major investigative stories on corporations and filed court cases to challenge the state and its relationship 
with the corporations. The $2 \mathrm{G}$ spectrum allocation controversy is the latest of such investigations, which is still unravelling in Indian courts.

Thakurta $^{4}(2012)$ says that communism has never been a pejorative in Indian politics as is the case elsewhere. Mainstream newspapers owned by big corporate entities like The Times of India or The Telegraph of Kolkata give space to left columnists and journalists even as the newspapers take a recognisable anti-left stand editorially.

Other than the journalists quoted here, there are many others who have been reporting on working class issues as well as environment, gender, trade unions, agrarian crisis and foreign affairs, shaping public opinion on policy issues.

\subsubsection{Language or Vernacular Journalism}

The Indian vernacular or language press has grown rapidly with improving literacy in the country. The largest circulated newspaper in the country is Dainik Jagran, a Hindi language newspaper with a circulation of 16.4 million copies. Other major language papers are Dainik Bhaskar (Hindi), Eenadu (Telugu), Malayala Manorama (Malayalam). In fact, The Times of India is the only English language paper that figures among the top ten papers in India. Since India is geographically divided based on the predominant language spoken in each region, the newspaper circulation is usually understood to cater to both the geographical area and the linguistic groups.

Apart from the staff reporters on the payroll, the language newspapers depend heavily on the informal networks of stringers who provide wide access to the far corners of each state. In Andhra Pradesh state, there are close to 9,000 stringers working for the newspapers.

Both the major left parties, CPI and CPIM run their own daily newspapers in addition to other publications. In addition to the party publications for their internal circulation, the radical left revolutionary groups have also developed access to the stringers of mainstream newspapers initially, and later the party cadre themselves began working as stringers and rural reporters with newspapers.

A study (Kasanagottu 1996, 202) says: "The cadres/supporters, sympathisers of left wing groups infiltrate the newspaper organisations. Former activists today occupy higher positions in the newspaper offices. ... The cadres also infiltrate the grassroots rural stringer network. These stringers are the major contributors of naxal $\left.\right|^{5}$ news in the columns of newspapers".

Kasanagottu states that newspaper managements also willingly or unwillingly recruit people associated with various Naxalite groups (Marxist-Leninists and sometimes also loosely referred to as Maoists) for two reasons. Firstly, the left wing sympathisers/activists have literary flair that can be exploited by newspapers. Secondly, the journalists' contacts with Naxalites make sensational stories possible, which would otherwise be difficult to get.

A study by Stevenson $(2000,228)$ says that some journalists have joined the Naxalites and some Naxalites have joined the ranks of journalists. Naxalites join a mainstream profession like journalism generally for reasons of personal safety. In Godavarikhani, a Staff Reporter of Vishalandhra (paper run by the Communist Party of India) joined the Jana Rakshana Samithi (roughly meaning, People's Protection Association). Later, he left the movement and started a Telugu weekly. However, he was killed in an "encounter". with the police.

Stevenson adds: "On the other hand, there are a sizeable number of stringers and contributors (no staff reporters) in each district who were earlier with the Naxalite movement and have surrendered. This only indicates how the press provides a cover for such activists and the power the press wields in society". He says, the left cadres believe that the law enforcement personnel are generally careful with journalists as it can lead to negative publicity.

This has been a major source of conflict between the state and media in the state's battle against left wing insurgencies. In states, where the insurgency has been long-term and low intensity for decades, many journalists have lost their lives on suspicion of being Maoist informers.

\footnotetext{
${ }^{4}$ Personal interview, 17 Jan

${ }^{5}$ 'Naxal' refers to the radical left groups who are waging an armed insurgency against the Indian state. The movement began in a place called Naxalbari in West Bengal in 1967.

* An 'encounter' is a euphemism for field executions by the security forces of the state. This has been a routine strategy of the state to 'deal' with left-wing extremist groups and their sympathisers in civil society.
} 
As many of the groups have been banned for several decades now, the journalists have been sources of information for the general public on the one hand and targets for state reprisals on the other. There are also instances when the revolutionary groups suspect their journalist conduits of being informants of the police and subject them to repression. The journalists working at the lowest rung of journalism, representing a wide range of ideological perspectives, are faced with pressures from both the security establishment of the state and the left groups (Lankesh 2010). Nevertheless, they open up spaces for left opinion in mainstream language journalism.

\section{Free Speech And Commercial Media In India}

The press in India has been working within the bourgeois liberal tradition. But within the intellectual and structural constraints of that system, there have been spaces for left-thought to articulate its position. If sometimes it is the ideology of the owners, sometimes it is the editor who makes these spaces available.

A more interesting phenomenon is the spaces created by the competitive market forces. According to Paranjoy Guha Thakurta ${ }^{6}$ (2012), when he offered a major investigative story to a news magazine, the story was turned down as the magazine just came out of a battle with the business group that was the subject of the news story. Thakurta offered the story to a widely circulated business daily from a powerful media house, which immediately picked up the story. Apart from the competitive edge, many journalists believe, it is easier for a major newspaper/media house to confront the power of the state and the corporations than for a smaller newspaper. The very diversity of the media industry makes space for dissent and debate possible, for whatever reason.

Another senior journalist, Mahesh Vijapurkar ${ }^{7}$ (2012), who worked with major newspapers like the Indian Express and The Hindu since the mid-1970s said that in his career, the editors never discouraged publication of a story because of a threat to their commercial interests. They merely ensured that public interest was served by the stories and that information was verified adequately before it was published. This was also reiterated by Paranjoy Guha Thakurta ${ }^{8}(2012)$, who said that both the corporate media houses and the editors of newspapers he has worked with gave considerable freedom to the journalists, as long as the information put out is sufficiently vetted and verified.

Interestingly, there are different perceptions among the journalists interviewed on the sources of threat to free speech in India. Sevanti Ninan ${ }^{9}$ (2012) says that journalists treat corporate issues with caution, sometimes because of the advertising clout of the corporations, but often also because the journalists have internalised the neo-liberal ideology. She also feels that the journalists may not see any of this as a free speech issue.

Mahesh Vijapurkar says the threat to free speech in India comes mostly from the internal dynamics of the media industry. According to him, top leadership of television networks instructing their reporters to hype up news stories on lean news days and to give opinion with news, poses a greater threat to credibility of news media. He also believes that the state or the politicians do not pose much threat to free speech because the privately owned media provide a powerful platform for them, despite the occasional transgressions.

In a similar vein, Vinod Mehta says: "Corruption is at the top, unfortunately, at the editor's level. It is at that level the agenda of a paper is decided. They have been compromised, have taken favours, have other interests and they are the people who have betrayed the profession".

A common factor among some of the senior journalists like Mehta, Thakurta and Sainath, who have built their reputation by writing on political and economic issues taking an anti-imperialist, antiglobalization stand, is also their faith in democracy and the role of journalism in enlarging opportunities for dissent and debate. Their contribution to keeping the left debate alive is as significant as the role of independent left journals like Mainstream and Economic and Political Weekly, as their

\footnotetext{
${ }^{6}$ Personal interview, 20 January.

${ }^{7} 17$ February. Telephone interview. Mahesh Vijapurkar has worked for The Hindu for over 30 years and worked with $D N A$ as fault finder.

${ }^{8}$ Personal interview, 20 January.

${ }^{9}$ Email interview. Sevanti Ninan is a senior journalist, columnist and editor of a media watch website The Hoot.
} 
publications are also more accessible to the general reader. The advertising agenda of their publications does not seem to impinge on their functioning as independent journalists, perhaps because there is a strong constituency for left opinion among readers.

It must be recognised, even if some journalists have bent to the commercial or political influences, the profession still has space for independent journalism.

The journalists working at the suburban and district levels have also kept up the news flow from remote locations about both the activities of the state and the left wing groups. However, they often bear the brunt of intolerance of dissent from the radical groups and repression of the state. In the heartland of Indian democracy, in the red corridor areas, affected states have promulgated draconian Newspeak laws like the Public Securities Acts, that allow arbitrary arrests of not only the activists of banned left political outfits, but also a complete blackout of information. Journalists are not allowed to enter some of these areas where paramilitary Special Forces are in control. Public intellectuals ${ }^{10}$ who raise human rights questions are arrested or have to face the threat of anachronistic sedition laws.

The commercial media are compelled to pay heed to public perceptions, if only to survive in the marketplace. It is this that facilitates reporting of state repression in the red corridor and arrests and assassinations of human rights activists in conflict areas in the mainstream media. To that extent, the mainstream media play an adversarial role. This is not to say that all reportage is unbiased and fair. The framing of the issues, the state machinery, politicians, bureaucracy, and the corporations using the media for "spin" is another debate. However, in a free speech environment, the truth surfaces on one platform or another and reaches the public, even when the news filters ${ }^{11}$ are constantly at work.

Though the mainstream commercial media provide spaces for the dissenting voices, the commercial content drowns out these voices, leading to a significant debate in recent times on the need to rein in commercial interests in the media, the role and desirability of press laws and censorship to preserve democratic values. There was a vociferous debate on mainstream media about the Indian state's attempt to censor intermediaries providing online services like Google, Facebook and Twitter. But a similar debate was not raised by either the "parliamentary left" or by the mainstream media about the blanket censorship and blackout of information in the red corridor areas and other "insurgency areas" of North-Eastern India or Kashmir.

The newspapers and publications of the left parties are moulded on the agit-prop mode and are clearly perceived as tools of propaganda both by the general reader and the parties themselves. The parliamentary left has deep ideological disagreement with the radical left groups waging a prolonged armed struggle against the state. But this has also stopped them from opposing vigorously the censorship and draconian laws that are being used by the bourgeois state. In the longterm, this can severely shrink the democratic spaces that are already eroding rapidly. The parliamentary left parties have been unable to encourage rigorous theoretical debate on issues because of what Prof Prabhat Patnaik (2011) in his incisive analysis calls "empericisation". He explains:

"What distinguishes a communist party is not that it does not 'soil its hands' with mundane, everyday politics, ... but that its process of engagement even at this level is imbricated by its project of transcending capitalism, informed by a consciousness of what Lukacs ${ }^{12}$ (1924) had called 'the actuality of the revolution'. ... If this theory linking the 'here and now' to the overall project of transcendence is absent from the praxis engaged in 'here and now', then we have a process of empericisation of the movement. ... Such empericisation in the context of our polity gives rise to at least

\footnotetext{
${ }^{10} \mathrm{Dr}$ Binayak Sen, a paediatrician working among the tribal communities was under arrest for several years and is given bail by the Supreme Court recently. Arundhati Roy, the author-activist was threatened with arrest for her views on Kashmir, under sedition laws.

${ }^{11}$ Noam Chomsky enumerates five filters in his discussion of the Propaganda Model in "Manufacturing Consent": Ownership of the medium, funding sources, sources, flak, anti-communist ideology.

${ }^{12}$ Lukacs, Georg (1924): Lenin: A Study of the Unity of His Thought, re-published by New Left Books, London, 1970.
} 
three kinds of tendencies: first, it gives rise to the range of 'sins' attributed to the party by its opponents ... such as careerism, 'satrapism', bureaucratism, and bossism at the local level. Secondly, it gives rise to a tendency to 'adjust' to given situations to prevent losses, instead of carrying it forward as a part of revolutionary praxis. This in turn entails a process of alienation of the party from the 'basic classes' that it is supposed to struggle for, viz, the workers, peasants, agricultural labourers, and the rural poor. The 'party interests' are seen in isolation from, and as being distinct from, the interests of the basic classes, and for the defence of the 'party interests' immediate, 'here and now' measures are thought of and resorted to, which may well diverge from the interests of the basic classes. Third, empericisation leads to a shrinking of the distance between the communist party and the other political formations"

In a contemplative piece about Com. K. Damodaran, one of the founders of the communist party of Kerala, his son K.P. Sasi (2012) gives insights into the working of the communist parties in India at various stages of recent history. It reveals the lack of democratic functioning, ideological helplessness battled by even the senior leadership in the left parties. Part of the problem also arises because of the failure of the left governed states in achieving visible transformation towards greater democratic freedoms or significantly better governance or material conditions.

Both the critiques reveal that there has been a gap between the ideological position of Marx and the practice of Marxism in India. Both these critiques show the need for the left parties of all shades to negotiate with and expand the scope of bourgeois freedoms, much like Marx, and to create conditions for transcending capitalism and imperialism. If within the parties there is no scope for free speech and democratic debate, it would not carry conviction to assert rights against the state and capital when those agencies choose to limit them. It is important to identify basic guiding principles and to institutionalise them, to adopt and strengthen positive features of liberal democracy in the transition to socialism and its transformed social content.

Freedom of the press is an essential part of the philosophical tradition of Marxism and has been an important instrument in Marxist praxis. According to Draper (1974a, 101-124): "For Marx, the fight for democratic forms of government - democratization in the state - was a leading edge of the socialist effort; not its be-all and end-all but an integral part of it all".

Draper (1974b, 118) also discusses what Marx refers to as the "Democratic Swindle". According to Draper, "Marx (in a letter to Engels on 14 September 1864) calls the United States "the model country of the democratic swindle" not because it was less democratic than others but for precisely the opposite reason. The fact that the US had developed the formal structure of the constitutional republic in the most democratic forms meant that its bourgeoisie likewise had to develop to its highest point the art of keeping the expression of popular opinion within channels satisfactory to its class interests... Marx or Engels analysed bourgeois-democratic politics as an exercise in convincing a maximum of the people that they were participating in state power, by means of a minimum of concessions to democratic forms." In India too, the formal structures of democracy have been in place for long but the bourgeoisie and capital have successfully "swindled" democracy in practice.

Therefore, the debate around bourgeois democracy versus socialist democracy is also significant for free speech. According to Sudipta Kaviraj:

"Democracy in principle (or as a whole) is not bourgeois - either in the sense of being conferred by the bourgeoisie on their people, or in being won by the struggles of the bourgeoisie. The general form of democracy today is a result won by proletarian and radical struggles to widen the narrow circle of political rights under liberal capitalism. It would be a great pity if democracy is not historically separable from the capitalist social form. In any case, the Marxian criticism of bourgeois democracy is not that capitalism realises democracy and that it is bad. Rather that what is bad about capitalism is that it does not realise democracy. As long as unequal classes exist, democracy must remain formal. This implies that when classes disappear, (under socialism) or nearly disappear, can the formal apparatuses of democracy enjoy real conditions of success" (Kaviraj 1989, 50-58). 
An important aspect of Marx's discussion of democracy was his views on bureaucracy. Marx understood that a bureaucracy could "own" a state as its private property and that when it did, it would make a fetish out of internal hierarchy and external secrecy. The democratic right to change policy, and own the state becomes possible when the citizens and workers, without risking anything can command those who carry out technical and administrative functions. If not, the bureaucracy tends to own the state as its private property (Harrington). In other words, the bureaucracy acts as an instrument of this "democratic swindle".

Marx's argument about free speech and censorship early in his career as a journalist was in opposition to the draconian Prussian laws of censorship that were being used as instruments to retard democratization. But when he founded the Neue Rheinische Zeitung with the support of liberals of Cologne who later became legislators and began to compromise their ideological positions for remaining in power, Marx was both brutal and relentless in his criticism. But his paper was shut down because of the censorship edicts of the time that he was challenging.

But in India, the Constitutionally guaranteed right to free speech, the diversity of voices in media has provided spaces for challenging the prevailing bourgeois consensus primarily because political parties market their policies in "public interest".

On the other hand, material reality of people has made radical politics inevitable in some parts of India, and sections of mainstream media misrepresent this reality, much as what Marx describes as the role of the British press in war-mongering during American Civil War, while the people were opposed to it (Marx, 1861). Marx also describes the nature of ownership and political pressures on the media, while recognising the honourable exceptions like The Spectator, The Examiner and MacMillan's Magazine in this article. The cartelization, the political ownership and emergence of oligopolies in Indian media industries is a looming threat to free speech.

In the later part of his life, Marx was living and working in Britain where censorship was not as problematic as it was in Germany of 1840s. During this phase, Marx was finding ways of using the freedoms available under bourgeois democracy to expand freedoms of the working classes. Marx, while engrossed in writing some of his classic works during this phase, used the newspaper columns to interpret the unfolding historical events from a class perspective. Whether as editor, correspondent or as opinion writer, it was fairly common to see Marx openly criticise newspapers by name, by specific pieces or stand taken by a newspaper on issues. Marx would subject them to logical, detailed criticism in an effort to provide the reading public with an alternate explanation. It is rare in Indian journalism to see criticism of rival papers, either ideologically or to challenge unethical practices ${ }^{13}$.

In the Indian context, though diversity of media industry aided by an independent judiciary and enabling legislations like the Right to Information Act has made exposing abuse of political, bureaucratic and corporate power possible, the interventions of the media tend to evoke different responses from the state depending on the perceived power of media to influence large segments of public opinion. When English language media with a large urban educated audience challenge the state, the state is compelled to respect the constitutional rights of the media to freedom of expression. In case of local media houses working in the hinterlands, the state cracks down heavily. Any transgressions by the regional language media (as in insurgency areas of the red corridor) are severely punished or suppressed by a slew of legislations that enable the state to suspend fundamental rights guaranteed by the Constitution of India. Many journalists have been shot dead in 'encounters'. In fact, over the years, this dual strategy has been adopted routinely by Indian state, giving India an image of a vibrant democracy, while great abuses of human rights also occur in large pockets of the country. It is also reflected in the perceptions of the senior journalists from national media who feel that the state is not as much of threat to free speech as the internal problems of the industry and the journalists' lack of integrity.

\footnotetext{
${ }^{13}$ In case of the "paid news" scandal that engulfed big media in India during the last parliamentary elections, several regional and national journalists wrote about and publicly denounced the practice of newspapers giving favourable coverage to rival candidates on hard news columns after accepting huge unaccounted-for payments. Press Council of India instituted a committee (with Paranjoy Guha Thakurta and Srinivas Reddy) to enquire into the affair. The report names several major newspapers indulging in this practice.
} 
The parliamentary left and the independent left have a greater role in challenging these tendencies of the bourgeois state. The independent left along with the journalists and left intellectuals working in the mainstream media are better placed to take up the challenge, because of their perceived independence and integrity. The parliamentary left faces more difficulties as the parties had opportunities to hold office through democratic elections and have been unable to unambiguously demonstrate the benefits that an elected Marxist government can yield, either through policies or through day-to-day issues of bureaucratic management.

According to Harrington, Marx defined socialism in the most profound sense of the word as the "truth of" bourgeois democracy, as democracy stripped of the structural limitations imposed on it by capitalist class society. The exposure of journalists at the ground level to the might of the state often make it possible for the mainstream media to exert pressure for asserting rights and policy change. The mainstream media in India have been a powerful presence in the political space of left politics, both as its critics and as its champions. The looming threat today is the consolidation of ownership, which till now has been diverse.

It is for the political entities of all hues that label themselves as Marxists, to recognise this truth and to work for the deepening and strengthening of democracy in India. The press is the most potent instrument for deepening democratic values and the wider and deeper engagement of the left in the critical segments of the media that are widely read, heard and seen is essential to this process.

\section{Conclusion}

Transcending the structural limitations of bourgeois democracy is the task before the left. Indian polity accepts a set of democratic ground rules and independent agencies like the judiciary and the Election Commission have been playing an important role in controlling both executive and corporate power to an extent. Sections of media have been a potent instrument and ally for both judiciary and the Election Commission in India.

Revisiting the free speech debate in the context of Marx's analysis makes it clear that it is necessary to ensure that independent constitutional authorities like the judiciary and the Election Commission are strengthened; strong press laws are enacted and enforced without curtailing freedom of the press; and censorship is challenged in all its forms, as it puts arbitrary power in the hands of the bureaucracy. The Indian experience also indicates that independent journalism that highlights the interests of the working class, despite the challenges it faces, can play a significant and historical role in politics of democratization and liberation.

\section{References}

Counter Currents website. 2012. http://www.countercurrents.org/aboutus.htm

Draper, Hal. 1974a. Marx on Democratic Forms of Government. In The Socialist Register. Accessed December 9, 2011. http://www.marxists.org/archive/draper/1974/xx/democracy.html

Economic and Political Weekly website. 2012. http://beta.epw.in/about us/

Emery, Michael, and Edwin Emery. 1954. The Press and America. NY: Prentice-Hall.

Frontier website. 2012. http://sites.google.com/site/frontierweekly/aboutfrontier

Frontline magazine. 2012. Accessed January 25, 2012. http://www.frontlineonnet.com/

Goyal, D.R. 1998. Remembering Nikhil Chakravartty. Economic and Political Weekly. XXXIII (29). July 18. 1911.

Hardt, Hanno. 2000. Communication is Freedom: Karl Marx on Press Freedom and Censorship. Javnost - The Public 7 (4): 85-100. Accessed November 26, 2011. http://javnost-thepublic.org/article/pdf/2000/4/6/

Kafila website. 2012. http://kafila.org/about/

Kaviraj, Sudipta. 1989. Perestroika: Reflections on the Theory of Power. Social Scientist 17 (194-195). July-August, 50-58. Ledbetter, James. 2007. Karl Marx: Dispatches for the New York Tribune. Edited by James Ledbetter, xix. NY: Penguin.

Marx, Karl. 1842a. On Freedom of the Press: Censorship. Rheinische Zeitung, 135, Supplement, May 15. Accessed December 10, 2011. http://www.marxists.org/archive/marx/works/1842/free-press/ch05.htm

Marx, Karl. 1842b. Debates on Freedom of the Press and Publication. In Karl Marx On Freedom Of The Press \& Censorship, edited and translated by Saul Padover, 27. NY: McGraw-Hill.

Marx, Karl. 1842c. Debates on Freedom of the Press and Publication. In Karl Marx On Freedom Of The Press \& Censorship, edited and translated by Saul Padover, 29. NY: McGraw-Hill.

Marx, Karl. 1842d. On Freedom of the Press: Censorship. Rheinische Zeitung, 135, Supplement, May 15. Accessed December 10, 2011. http://www.marxists.org/archive/marx/works/1842/free-press/ch05.htm 
Marx, Karl. 1842e. As a Privilege of Particular Individuals or a Privilege of the Human Mind? Rheinische Zeitung, May 12. Accessed December 10, 2011. http://www.marxists.org/archive/marx/works/1842/free-press/ch04.htm

Marx, Karl. 1842f. Debates on Freedom of the Press and Publication. In Karl Marx On Freedom Of The Press \& Censorship, edited and translated by Saul Padover, 39. NY: McGraw-Hill.

Marx, Karl. 1842g. Debates on Freedom of the Press and Publication. In Karl Marx On Freedom Of The Press \& Censorship, edited and translated by Saul Padover, 40-41. NY: McGraw-Hill.

Marx, Karl. 1848. The Neue Berliner Zeitung on the Chartists. Neue Rheinische Zeitung, June 24. Accessed December 10 2011. http://www.marxists.org/archive/marx/works/1848/06/24b.htm

Marx, Karl. 1848. The Prussian Press Bill. Neue Rheinische Zeitung, July 19. Accessed December 12, 2011. http://www.marxists.org/archive/marx/works/1848/07/20a.htm

Marx, Karl. 1843. The Mosel Region and the Cabinet Order of December 24, 1841. In Karl Marx On Freedom Of The Press \& Censorship, edited and translated by Saul Padover, 77. NY: McGraw-Hill

Marx, Karl. 1861. The Newspapers and the Opinion Of The People. Die Presse, 25 December. Accessed March $25,2012$. http://www.marxists.org/archive/marx/works/1861/12/31.htm

Mehta, Vinod. 2012a. Interview with Sheela Bhatt. Accessed January 26, 2012. http://www.rediff.com/news/slideshow/slide-show-1-corruption-unfortunately-is-at-the-editor-level/20120130.htm

Mehta, Vinod. 2012b. Interview with Sheela Bhatt. Accessed January 26, 2012. http://www.rediff.com/news/slideshow/slide-show-1-corruption-unfortunately-is-at-the-editor-level/20120130.htm

Menon, Nivedita. 2011. 'End of the Left' in India? Statement by Leftists after Recent Election Results. 24 May. KAFILA. Accessed January 25, 2012. http://kafila.org/2011/05/24/end-of-the-left-in-india-statement-after-recent-election-results/

Musto, Marcello. 2008. Karl Marx's Grundrisse: Foundations of the Critique of Political Economy 150 Years late. Oxon, UK: Routledge.

Nair, Somasekharan K. G. 2009. Indian Communists versus Marxism-Leninism. Mainstream. XLVII(34) 8 Aug. Accessed February 2, 2012. http://www.mainstreamweekly.net/article1558.html

Padover, Saul. K. 1974. Karl Marx On Freedom Of The Press \& Censorship. Edited and translated by Saul Padover, xi. NY: McGraw-Hill.

Padover, Saul. K. 1974. Karl Marx On Freedom Of The Press \& Censorship, edited and translated by Saul Padover, xiii. NY: McGraw-Hill.

Palagummi, Sainath. 2011. Interview with NewsClickin. 22 June. Accessed January 25, 2012. http://www.youtube.com/watch?feature=endscreen\&NR=1\&v=bu9W53Skr28

Palagummi, Sainath. 2011. Interview with NewsClickin. 22 June. January 25, 2012. http://www.youtube.com/watch?v=QewCqpgBiuw\&feature=related

Pucchalapally, Sundarayya. 1971a. Telangana People's Armed Struggle, Part 2. 27-35. Accessed on February 5, 2012. http://www.scribd.com/doc/15380676/Telangana-Peoples-Armed-Struggle-19461951-Part-Two-First-Phase-and-ltsLessons

Pucchalapally, Sundarayya. 1971b. Telangana People's Armed Struggle, Part 2. 42. Accessed February 5, 2012. http://www.scribd.com/doc/15380676/Telangana-Peoples-Armed-Struggle-19461951-Part-Two-First-Phase-and-ItsLessons

Pucchalapally, Sundarayya. 1971c. Telangana People's Armed Struggle, Part 2. 35-36. Accessed February 5, 2012. http://www.scribd.com/doc/15380676/Telangana-Peoples-Armed-Struggle-19461951-Part-Two-First-Phase-and-ltsLessons

Rajimwale, Anil. 2009a. Ajoy Ghosh: The Creative Marxist. Mainstream. XLVIII (1) 26 Dec. Accessed February 2, 2012. http://www.mainstreamweekly.net/article1843.html

Rajimwale, Anil. 2009b. Ajoy Ghosh: The Creative Marxist. Mainstream. XLVIII (1) 26 Dec. Accessed February 2, 2012. http://www.mainstreamweekly.net/article1843.html

RNI website. 2012. Accessed January 25, 2012. https://rni.nic.in/

Thakurta, Paranjoy Guha. 2012. Media Ethics. N. Delhi: Oxford.

The Economist. 2010. Maoist Insurgents in India: More Bloody and Defiant. 22 July. Accessed January 25, 2012. http://www.economist.com/node/16650478

The Hindu Website. 2012. Accessed January 25, 2012. http://www.thehindu.com/navigation/?type=static\&page=aboutus

\section{About the Author}

Padmaja Shaw

graduated with a Masters degree in Journalism from Osmania University, India, and an MA (Telecommunications) from Michigan State University, USA. She completed a PhD in Development Studies and has been teaching at the Department of Communication and Journalism, Osmania University, India, since 1988. She has two tracks of interest: Broadcast production and political economy of communication. She contributes regularly to a media watch website, The Hoot, and writes a regular column in a local English language daily newspaper, The Hans India. 